2014, volume 3, issue 1

Szlęzak-Matusewicz J. (2014). Models of Tax Incentives for R\&D Activities of Enterprises in European Union Countries. Copernican Journal of Finance \& Accounting, 3(1), 145-160. http://dx.doi.org/10.12775/CJFA.2014.012

Joanna Szlęzak-Matusewicz*

Warsaw School of Economics

\title{
MODELS OF TAX INCENTIVES FOR R\&D ACTIVITIES OF ENTERPRISES IN EUROPEAN UNION COUNTRIES
}

Keywords: tax incentives, research and development activities, tax credit.

J E L Classification: H21, 030.

Abstract: An aim of the author's considerations contained in the article is to describe the models of tax incentives supporting research and development activity carried out by enterprises in European Union countries, with a particular consideration of Polish solutions as well as their attractiveness from the enterprises' point of view. To achieve the objectives there were analyzed reports and surveys conducted by international organizations as well as presented the generosity level of tax incentives in different countries. There is also evaluation of Polish legal regulations supporting R\&D activities, pointing out the potential directions of change in tax law.

\section{MODELE ULG PODATKOWYCH NA DZIAŁALNOŚĆ BADAWCZO-ROZWOJOWĄ PRZEDSIĘBIORSTW W KRAJACH UNII EUROPEJSKIEJ}

Słowa kluczowe: ulgi podatkowe, działalność badawczo-rozwojowa, kredyt podatkowy.

Klasyfikacja J E L: H21, 030.

Abstrakt: Celem rozważań prowadzonych w artykule jest charakterystyka modeli ulg podatkowych wspierających działalność badawczo-rozwojową przedsiębiorstw w kra-

Date of submission: February 27, 2014; date of acceptance: March 3, 2014.

* Contact information: joanna.szlezak@sgh.waw.pl, Institute of Finance, Warsaw School of Economics, Al. Niepodległości 162, 02-554 Warszawa, Poland, phone: 225649295. 
jach Unii Europejskiej ze szczególnym uwzględnieniem rozwiązań polskich, a także ich atrakcyjności z punktu widzenia przedsiębiorstw. W tym celu autorka przeanalizowała badania oraz raporty prowadzone przez międzynarodowe organizacje prezentując jednocześnie poziomy „hojności” ulg w poszczególnych krajach. W artykule dokonano także oceny polskich rozwiązań w zakresie wspierania działalności badawczo-rozwojowej przedsiębiorstw wskazując ewentualne kierunki zmian przepisów.

Translated by Joanna Szlęzak-Matusewicz

\section{IIINTRODUCTION}

Research and development (R\&D) ${ }^{1}$ is considered as a basic ingredient of economic growth. Both economic theory and empirical evidence support the view that R\&D plays a vital role in raising productivity on a sustainable basis (Romer 1990, 71-101). Therefore, in many countries, there is carried out an active innovation-related policy. Among the innovation-targeted policy's tools, which are, among other things, regulations in the area of patent law or spending funds on research and development, as well as on education, there must also be mentioned fiscal instruments which include tax incentives.

An aim of the author's considerations contained in the article is to describe the models of tax exemptions supporting research and development carried out by enterprises in the European Union countries, with a particular consideration of Polish solutions as well as their attractiveness from the enterprises' point of view.

\section{THE RESEARCH METHODOLOGY}

\section{AND THE COURSE OF THE RESEARCH PROCESS}

The paper contains descriptive research studies. To achieve the objectives there were analyzed reports and surveys conducted by international organizations (e.g. OECD). The analysis of different models of tax incentives supporting R\&D activities supporting R\&D activities let the author draw the conclusions concerning Polish legal regulations. On the basis of the conclusions the author designated the desired shape of Polish tax incentive for R\&D activity.

${ }^{1}$ Research activity and development work, R\&D in its abbreviated form, comprises a creative work undertaken in a systematic way for the purpose of extension of the sources of knowledge, including the knowledge of the human being, culture and society as well as the use of those resources for the purpose of creating new applications. 


\section{EXPENDITURES ON RESEARCH AND DEVELOPMENT}

\section{IN POLAND AGAINST THE BACKGROUND OF EUROPEAN UNION COUNTRIES}

One of the five headline targets of the Europe 2020 Strategy is to achieve an R\&D intensity (R\&D expenditure as a percentage of GDP) of 3\% in the EU. However, the EU countries have certain difficulties with meeting the expectations. In 2011, R\&D intensity in the EU-27 stood at 2.03\%. It was below the figures recorded in Japan (in 2009: 3.36\%), South Korea (2010: 4\%) and the United States (2009: 2.87\%), but higher than in China (2009: 1.7\%). Among the EU Member States, only Finland (3.78\%), Sweden (3.37\%) and Denmark (3.09\%) exceeded the EU goal of devoting 3\% of GDP to R\&D, also outperforming the United States. Other seven Member States, namely Germany (2.84\%), Austria (2.75\%), Slovenia (2.47\%), Estonia (2.38\%), France (2.25\%), the Netherlands and Belgium (both 2.04\%) were above the EU-27 average although below the target figure of $3 \%$. Poland is at the end of the statistics allocating only $0.76 \%$ of GDP for R\&D in 2011 (Eurostat 2013).

Though the index for Poland is one of the lowest in the international comparisons, its value is growing from one year to another. The relatively biggest growth was noted in 2012 (more than 18\%), see Table 1.

Table 1. GERD related to GDP

\begin{tabular}{|l|c|c|c|c|c|}
\hline \hline \multicolumn{1}{|c|}{ Specification } & $\mathbf{2 0 0 8}$ & $\mathbf{2 0 0 9}$ & $\mathbf{2 0 1 0}$ & $\mathbf{2 0 1 1}$ & $\mathbf{2 0 1 2}$ \\
\hline \hline $\begin{array}{l}\text { Domestic expenditure on } \\
\text { R\&D (GERD) (million PLN) }\end{array}$ & 7706 & 9070 & 10416 & 11687 & 14353 \\
\hline GDP (million PLN) & 1275508 & 1344505 & 1416585 & 1528127 & 1595225 \\
\hline GERD related to GDP (\%) & 0.6 & 0.67 & 0.74 & 0.76 & 0.9 \\
\hline \hline
\end{tabular}

S o u r c e : Central Statistical Office (GUS) 2013.

According to the methodology adopted after the OECD, entities carrying out or financing research and development are grouped by the so-called institutional sectors, among which there are distinguished the following ones: the sector of business enterprises, government, higher education, private nonprofit, and abroad. An important element in the evaluation of economy innovativeness is an analysis of the structure of origin of the funds financing $R \& D$, which, in the international comparisons, is carried out through identification of the sector from which there originated the funds being the source of financ- 
ing. The share of the sector of enterprises in financing R\&D is growing from one year to another. In 2010, it accounted for $24.4 \%$, in 2011 - for $28.1 \%$, and in $2012-32.3 \%$ (GUS 2013). However, these values differ significantly from the European Union's average where $53.9 \%$ of expenditures on $R \& D^{2}$ are financed by the sector of enterprises. The leaders in this classification are Finland, Sweden, and Slovenia, where $75 \%$ or more of R\&D activities are financed on the basis of the private sector. The comparison of Poland with its natural competitors - the Czech Republic and Hungary - is not satisfactory, either. The index in both these countries accounts for $47 \%$ (Eurostat 2013).

The level of investments in R\&D depends on enterprises' decisions on the amount of funds allocated for R\&D. However, enterprises do not invest in R\&D heavily compared to other spheres of their activity. A certain number of reasons can explain this situation. First of all, firms have difficulties to fully appropriate the returns on their investment as some of the resulting knowledge will leak out or spill over to other firms, to the benefit of the society. Firms have also difficulties in finding external finance and qualified people to conduct research. Besides, results of R\&D research are unknown and require a long time to appear. It is emphasised that despite the expectations not always greater expenditures on R\&D are attributed to higher profit (Coad, Rao 2010). Therefore, investment in R\&D is considered to be very risky. Nonetheless, taking into consideration the fact that the current source of economic growth will be exhausting e.g. low labour cost, natural recourses availability, EU accession, good location, one should search for new sources of the competitive advantage. One of the possible ways to sustain the stable economic development is to invest into innovation that leads to industry restructuring and creating new business models (Wiśniewska, Janasz 2013, 18). Unfortunately, this solution is extremely difficult to implement in such countries as Poland. In the literature, it is stressed that one of the biggest problem of the economic growth in the countries that passed through the systemic transformation is to overcome anti-innovative approach to all aspects of business life, including innovation (Bal-Woźniak 2012, 38). Therefore, the risk concerning R\&D should be divided between the enterprise that invests into R\&D and the government who should support such entity by using direct or indirect methods.

${ }^{2}$ Data for the year 2010. 


\section{MODELS OF TAX INCENTIVES FOR R\&D}

Governments can use different mechanisms to stimulate business R\&D including direct funding of private R\&D and fiscal incentives. Each form of stimulating R\&D activities has advantages and disadvantages. The direct funding, e.g. credit loans, grants, equity financing of industry research allows governments to retain control over the nature of R\&D conducted. Thus, the social and economic policy of the government can be realised because subsidies are aimed at a particular sector of the economy, e.g. health care. Moreover, direct funding of business R\&D has a positive effect on gaining external source of financing, especially by small and medium-sized enterprises. However, direct supporting of industry R\&D can be a source of the distortion in market competition.

Unlike, fiscal incentives are addressed to a broad circle of recipients leaving them independence in the context of how to spend funds on R\&D. By reducing the cost of R\&D, fiscal reliefs raise the net present value of prospective research projects. Fiscal measures do not distort market decisions. If properly designed, they can have lower administrative costs for the government than other types of programmes or supports, although tax incentives can be extremely costly in terms of budget expenditures. Besides, using of the tax incentives is possible if the enterprise generates income or tax liabilities. Thus, indirect system of supporting eliminates small and young companies from the circle of beneficiaries although they are treated as the most innovative (Czerniak 2013, 83). The choice of the mechanisms of supporting (direct or indirect) depends mainly on the innovation policy mix and economic targets. If the government's aim is an increase of the total level of R\&D expenditures, tax incentives are a better solution. On the other hand, if the government aims for financial supporting a particular stage of $R \& D$ research, then direct financing is more efficient.

However, the general trend across countries has been to increase the availability and generosity of R\&D tax incentives, making the policy mix more indirect over time (OECD 2012, 157). That is why more and more countries implement tax incentives to their economic strategy. R\&D tax incentives are widely used in OECD and non-OECD countries. According to OECD, 27 out of the 34 OECD member countries offer R\&D tax incentives to business. ${ }^{3}$ The existing $R \& D$ tax incentives regimes differ significantly across countries in terms of

3 Data for the year 2011. 
their generosity, their design and how they explicitly target different firms or specific areas.

Fiscal incentives for R\&D usually take one of the four forms (STI 2004, 12; Mohnen 1999, 2; Stewart, J. Warda, R. D. Atkinson 2012, 3):

- tax credits which are the amounts deducted from tax liabilities,

- tax allowances which are amounts deducted from gross income,

- tax deferrals which are reliefs in the form of delay in the tax payment,

- preferential tax rates.

Tax credits are specified percentage of R\&D expenditures, which are applied against payable income tax, while an allowance is a deduction from the taxable income. Thus, the value of tax allowance depends on the income tax rate, while a tax credit does not. This is of a particular importance in case of the progressive tax scale whose diversified tax rates affect the amount of deduction. Another distinction between tax allowance and tax credit concerns the possibility to carry the non-deducted from income expenses forward to next years. In the case of exemption, such possibility, as to the principle, does exist. On the other hand, in the case of tax credit, such possibility does not exist, unless there is established a mechanism allowing for settlement of reimbursement of expenses incurred.

Both, tax credits and tax allowances, are of three types depending on whether they are based on deductions based on the volume of R\&D expenditure (volume incentives), deductions based on increment of that volume (incremental incentives). The third type is a hybrid of the two earlier deductions. It's hard to provide an unequivocal answer, which solution - volume incentives or incremental incentives - better affects stimulation of research and development activity. A defect of the solution based on expenditure volume is that it does not support exclusively new spending but also that which the entrepreneur would have incurred if deduction did not exist. In turn, the solution based on incremental expenditures depends on the amount assigned on the grounds of changes in R\&D expenditures. This is a significantly cheaper solution for the state budget compared to the relief depending on the expenditure volume. On the other hand, in the construction of deduction based on incremental expenditure, there is bypassed the fact of the cyclical nature of $R \& D$ expenditure. This feature causes that lack of incremental expenditures in a certain period will result in lack of the opportunity to make use of an incentive despite reporting the activeness in the R\&D sphere. However, this problem will not be seen in the case of volume incentive. 
Tax deferrals can appear as an accelerated depreciation which allows firms to reduce the value of a fixed asset involved in $R \& D$ a higher rate during the early years of the asset's lifespan, yielding a larger deduction over the lifespan of the asset relative to normal depreciation rates.

The analysis of tax solutions occurring in various countries compels to indicate the fourth model of tax preferences stimulating growth of R\&D expenditures, i.e. the preferential tax rates. As an example there may be indicated France, which applies a reduced income tax rate relative to revenues obtained from sales of a patent, or also the Netherlands - in the case of income from innovative activities (OECD 2012, 157).

Expenditures incurred by entrepreneurs on research and development may be divided into two groups: investment (capital) expenses and current costs. The former comprise expenditures on new fixed assets connected with R\&D, purchase (acquisition) of second-hand fixed assets as well as on the initial equipment of investments not included to fixed assets, while purchased from investment funds (GUS). The second group of expenses, significantly more important, comprises personnel outlays as well as costs of consumption of materials, nondurable objects and energy, costs of services made by other contractions (other than R\&D) including: third-party processing, transport, repair, bank, postal, telecommunication, information technology, publishing, municipal, etc. services, costs of business trips and other current costs including, in particular, taxes and fees charged on costs of operating activity and profits, property insurance and equivalents to the benefit of employees - in the part in which they are related to the R\&D activity. Total current expenditures do not include depreciation of fixed assets as well as VAT (GUS). Comparing the amount of both expenditures, it appears that it is current expenditures what constitutes the main factor of investment. In Poland, current expenditures accounted in 2012 for 69\% (GUS 2012) of expenditures incurred by enterprises on R\&D activity. ${ }^{4}$

\section{REVIEW OF THE RESEARCH CONCERNING THE IMPACT OF TAX INCENTIVES ON R\&D ACTIVITY OF ENTERPRISES}

Research on the impact of tax incentives supporting R\&D activities on enterprises' activity in the R\&D sphere has been carried out for many years. Most re-

\footnotetext{
${ }^{4}$ In developed countries, this ratio is estimated at the level of 90\%; after: (Hall 1995).
} 
search has been conducted in the United States and Canada. As an example we can indicate research of N. Bloom, R. Griffith and J. Van Reenen (2002) who examined the impact of fiscal incentives on the level of R\&D investment. They have created an econometric model of R\&D investment using a new panel of data on tax changes and R\&D spending in nine OECD countries over a 19-year period (1979-1997). They have found evidence that tax incentives are effective in increasing R\&D intensity.

D. Czarnitzki, P. Hanel and J. Rosa (2011) have presented the study that examined the effect of R\&D tax credits on innovation activities of Canadian manufacturing firms. They have investigated the average effect of R\&D tax credits on a series of innovation indicators such as: number of new products, sales with new products, originality of innovation, etc. using a non-parametric matching approach. Compared to a hypothetical situation in the absence of R\&D tax credits, recipients of tax credits showed significantly better scores on most but not all performance indicators. Therefore, they have concluded that tax credits lead to additional innovation output.

Few countries have performed as many studies of their tax incentives supporting R\&D activity as the US and Canada. According to Hall and Van Reenen (2000) there are several reasons for this: 1 . Most of these schemes have been in place for a shorter time period. 2. They have relied on the US evaluations for evidence of effectiveness. 3. Internal government studies may have been done, but these are hard to come by if you are not connected with researchers within the government in question.

However, in recent time, we can find some research in Europe, especially in countries where new package of tax incentives has been introduced. A. Cappelen, A. Raknerud and M. Rybalka (2012) have examined a tax-based incentive on R\&D - SkatteFUNN - that was introduced by Norwegian government in 2002. They have analyzed the effects of SkatteFUNN on the likelihood of innovating and patenting. Using a rich database for Norwegian firms, they have found that projects receiving tax credits result in the development of new production processes and to some extent the development of new products for the firm. However, the scheme does not appear to contribute to innovations in the form of new products for the market or patenting.

There are different methods of the research on effectiveness of the tax incentives. A the first way to evaluate the effectiveness of R\&D tax reliefs is to compare the R\&D expenditures before and after changes in tax incentives to R\&D. Using this method J. Cordes (1989) have showed that R\&D increased in 
the United States after the passage of the Economic Recovery Tax Act of 1981 and the Tax Equity and Fiscal Responsibility Act of 1982 and continued to be strong despite the economic recession. Another approach is a survey. E. Mansfield and L. Switzer (1985) conducted a survey of 55 Canadian companies. The results revealed that $\mathrm{R} \& \mathrm{D}$ generated by tax incentives did not amount to more than $40 \%$ of the lost tax revenue. The third approach to the evaluation of R\&D tax incentives consists in estimating the relationship between R\&D and tax incentives by econometric methods. The representatives of this stream is, among others, B. Hall (1993).

One of the indices used in the OECD comparative analyses is the so-called Bindex (Warda 2006, 34) designed by J. Warda, which measures the relative cost effectiveness of $R \& D$ expenditures in a given tax regime. The B-index expresses the minimum cost effectiveness relationship with which investment in R\&D becomes paying under the conditions of a given tax regime. In international comparisons, the more frequently used index is the tax subsidy ratio being a difference between 1 and the B-index. An index higher than 0 means that the tax regulations allow reduction of tax liabilities of the enterprise investing in R\&D by more than the amount of expenditures actually incurred for that purpose. In such situation, one may ascertain that incentive effectiveness by way of subsiding $R \& D$ activity is apparent. And if the index is equal to 0 or lower than 0 , the tax regime remains neutral or affects negatively on enterprises' activeness as regards $R \& D$ (see Table 2).

Table 2. Tax subsidy ratio in some countries (2012)

\begin{tabular}{|l|l|}
\hline \multicolumn{1}{|c|}{ Country } & \multicolumn{1}{c|}{ Tax subsidy ratio } \\
\hline \hline France & 0.43 SME and 0.34 large firms \\
\hline Portugal & 0.41 \\
\hline Ireland & 0.13 \\
\hline Austria & 0.12 \\
\hline Netherlands & 0.33 SME and 0.14 large firms \\
\hline Denmark & 0.29 \\
\hline Hungary & 0.22 \\
\hline Belgium & 0.14 \\
\hline United Kingdom & 0.28 SME and 0.11 large firms \\
\hline Slovenia & 0.05 \\
\hline
\end{tabular}




\begin{tabular}{|l|l|}
\hline \hline \multicolumn{1}{|c|}{ Country } & \multicolumn{1}{c|}{ Tax subsidy ratio } \\
\hline \hline Norway & 0.25 SME and 0.22 large firms \\
\hline Spain & 0.35 \\
\hline Czech Republic & 0.20 \\
\hline Germany & -0.02 \\
\hline Sweden & -0.01 \\
\hline Finland & -0.01 \\
\hline Luxembourg & -0.01 \\
\hline Switzerland & -0.01 \\
\hline Poland & -0.01 \\
\hline Italy & 0.12 \\
\hline Slovak Republic & -0.01 \\
\hline Greece & 0.01 \\
\hline \hline
\end{tabular}

S o u r c e : Stewart, Warda, Atkinson 2012.

\section{R\&D INCENTIVES IN EUROPEAN UNION COUNTRIES}

The most advantageous for enterprises incentives systems are in force in France, Spain, Portugal, Hungary, and in the Czech Republic. This is evidenced by a relatively high tax subsidy ratio whose value, among the EU countries, is the highest in Portugal, France and Spain. Table 3 contains the solutions adopted in the European Union Member States with the highest tax subsidy ratio. On the other hand, there are not anticipated R\&D incentives in the legislations of, inter alia, Finland, Germany and Sweden (OECD 2012, 157). Nevertheless, in these countries an activator of $R \& D$ activity is an extensive cooperation between enterprises and research institutes. 
Table 3. Description of the basic ${ }^{5}$ tax allowances in some countries

\begin{tabular}{|c|c|c|c|c|c|c|c|}
\hline \multirow{2}{*}{ Country } & \multirow{2}{*}{$\begin{array}{c}\text { Tax rate } \\
(\%)\end{array}$} & \multicolumn{2}{|c|}{ Tax allowance } & \multicolumn{2}{|c|}{ Tax credit } & \multirow{2}{*}{$\begin{array}{l}\text { Eligible expen- } \\
\text { ditures }\end{array}$} & \multirow{2}{*}{$\begin{array}{l}\text { Tax subsidy } \\
\text { ratio }\end{array}$} \\
\hline & & volume & $\begin{array}{l}\text { incre- } \\
\text { mental }\end{array}$ & volume & incremental & & \\
\hline Austria & 25 & & & $10 \%$ & & $\begin{array}{l}\text { Current expen- } \\
\text { ditures and } \\
\text { capital expen- } \\
\text { ditures }\end{array}$ & 0.12 \\
\hline $\begin{array}{l}\text { Czech } \\
\text { Rep. }\end{array}$ & 19 & $200 \%$ & & & & $\begin{array}{l}\text { Current expen- } \\
\text { ditures and } \\
\text { capital expen- } \\
\text { ditures }\end{array}$ & 0.20 \\
\hline France & 33.33 & & & $\begin{array}{l}30 \% \text { of expen- } \\
\text { ditures related } \\
\text { to the amount } \\
\text { of } 100 \mathrm{~m} \text { euros } \\
\text { and } 5 \% \text { of } \\
\text { expenditures } \\
\text { above } 100 \mathrm{~m} \\
\text { euros }\end{array}$ & & $\begin{array}{l}\text { Current expen- } \\
\text { ditures and } \\
\text { capital expen- } \\
\text { ditures }\end{array}$ & $\begin{array}{l}0.34 \text { in case } \\
\text { of large en- } \\
\text { terprises and } \\
0.43 \text { in case } \\
\text { of enterprises } \\
\text { from the SME } \\
\text { sector }\end{array}$ \\
\hline \multirow[t]{2}{*}{ Spain } & \multirow[t]{2}{*}{30} & \multirow[t]{2}{*}{$\begin{array}{l}50 \% \text { of } \\
\text { proceeds } \\
\text { on patent } \\
\text { rights } \\
\text { assign- } \\
\text { ment }\end{array}$} & & 25 & $\begin{array}{l}+42 \text { of the } \\
\text { amount of } \\
\text { excess of total } \\
\text { R\&D expendi- } \\
\text { tures related } \\
\text { to the mean } \\
\text { of the two last } \\
\text { years }\end{array}$ & $\begin{array}{l}\text { Current expen- } \\
\text { ditures }\end{array}$ & \multirow[t]{2}{*}{0.35} \\
\hline & & & & $8 \%$ & & $\begin{array}{l}\text { Capital expen- } \\
\text { ditures except } \\
\text { for buildings }\end{array}$ & \\
\hline Portugal & $12.5-27.5$ & & & $32.5 \%$ & $\begin{array}{l}+50 \text { of the } \\
\text { amount of } \\
\text { excess of total } \\
\text { R\&D expendi- } \\
\text { tures related } \\
\text { to the mean } \\
\text { of the last two } \\
\text { years (maxi- } \\
\text { mum to the } \\
\text { level of } 1.5 \text { mil- } \\
\text { lion euros) }\end{array}$ & $\begin{array}{l}\text { Current expen- } \\
\text { ditures and } \\
\text { capital expen- } \\
\text { ditures }\end{array}$ & 0.41 \\
\hline
\end{tabular}

${ }^{5}$ Besides the incentives specified in Table 3, there are also other reliefs envisaged in legislations of individual states. For example, they may be allowances related to payment of wages and salaries for employees involved in R\&D activity or the preferential rates of taxation of licensing revenues. 


\begin{tabular}{|c|c|c|c|c|c|c|c|}
\hline \multirow{2}{*}{ Country } & \multirow{2}{*}{$\begin{array}{c}\text { Tax rate } \\
(\%)\end{array}$} & \multicolumn{2}{|c|}{ Tax allowance } & \multicolumn{2}{|c|}{ Tax credit } & \multirow{2}{*}{$\begin{array}{l}\text { Eligible expen- } \\
\text { ditures }\end{array}$} & \multirow{2}{*}{$\begin{array}{l}\text { Tax subsidy } \\
\text { ratio }\end{array}$} \\
\hline & & volume & $\begin{array}{l}\text { incre- } \\
\text { mental }\end{array}$ & volume & incremental & & \\
\hline Hungary & $10 / 19$ & $\begin{array}{l}200 \% \\
+100 \% \text { in } \\
\text { case of } \\
\text { coopera- } \\
\text { tion with } \\
\text { research } \\
\text { institutes }\end{array}$ & & & & & 0.22 \\
\hline Poland & $18 / 32$ or 19 & $150 \%$ & & & & $\begin{array}{l}\text { Only intangible } \\
\text { assets set forth } \\
\text { in the act }\end{array}$ & -0.01 \\
\hline
\end{tabular}

S o u r c e : Own compilation based on: Stewart, Warda, Atkinson 2012; OECD 2011; Deloitte 2013.

Reliefs and incentives occurring in the EU countries have the form (in most cases) of tax credit based on the volume of R\&D expenditures (volume incentives). Recently, there can be seen the trend to replace deductions determined on the incremental basis by deduction depending on the volume of outlays. Adoption of this solution, although certainly more expensive for the state budget, is simpler in introduction and better motivates entrepreneurs for R\&D activeness in the situation of economic slowdown.

The years of the financial crisis are a period of reforming of R\&D incentives regimes. The general trend taking place in the majority of OECD Member States is growth of relief accessibility, amount of deductions as well as simplification of the relief construction. As an example there can be indicated France where in 2008 the complicated hybrid mechanism of deductions was replaced by a simple R\&D expenditure volume incentive.

The basis for deductions in the European solutions is, first of all, current expenditure, inclusive of, inter alia, remuneration of the employees involved in research and development activity, exploitation costs, materials, costs of energy, etc. Deductible are also capital expenditures, albeit, in this case, there may take place some limitations (e.g. exclusions related to buildings).

The R\&D incentive ${ }^{6}$ theoretically exists also in the Polish legal order, although in reality it does not anything common with the classical R\&D incentive taking place in other countries of the European Union (Ustawa 1992, art 18b;

${ }^{6}$ In the article, there is abandoned the incentive issuing from having the status of R\&D centre due to very restrictive conditions to be met to be eligible to preferences. In 2013, there were only 28 such entities; after: http://bip.mg.gov.plChile/Jednostki+organizacyj 
Ustawa 1991, art 26c). The construction of relief for purchase of new technologies allows deducting from the taxation base $150 \%$ of the expenses incurred, of which $100 \%$ on the general principle, most often within depreciation, and the additional $50 \%$ within the framework of the relief. Theoretically the tax advantage is apparent. In practice, however, it is unnoticeable by entrepreneurs who do not display any major interest in deductions. In 2012, only 42 enterprises taxed by the personal income tax and 94 - by the corporate income tax exercised the right to make use of the allowance. In earlier years, the trend was similar. ${ }^{7}$ This is also confirmed by the annual data published by the OECD, in accordance to which the ratio of use R\&D incentive related to GDP is zero, whereas in the Czech Republic it accounts for $0.028 \%$, in Hungary - for $0.09 \%$, in Portugal - for $0.172 \%$, and in France, which takes the first position in this classification - for $0.261 \%$ (OECD 2012, 162).

Impact of the tax incentive on enterprises' activeness in the R\&D sphere measured by the tax subsidy ratio $(-0.01)^{8}$ has a reverse direction than the intended one. Such a construction of the incentive causes that every zloty invested in R\&D activity by the entrepreneur has to add 1 grosz, whereas, for example, in Hungary, from every 100 invested forints the entrepreneur recovers more than 22 forints.

The tax incentive in Poland, therefore, is not a factor activating the R\&D sphere of entrepreneurs, and the reasons for that must be seen, first of all, in the too narrow base of deduction-eligible expenditures. Deductions comprise only expenses incurred on intangible assets purchased by the taxpayer. This means that if the entrepreneur carries out the research and development activity on their own account, they cannot count on tax preferences because the inventive rewards exclusively acquisition and not production of intangible assets. Therefore, the direction of the Polish tax incentive is opposite compared to the solutions adopted in other countries. In those countries, the relief includes, first of all, entrepreneurs' current expenditures on their own research.

Therefore, if in Poland the legislator has anticipated in the innovation-related policy an indirect support for activities in the R\&D sphere by way of fiscal instruments, the regulations in this area should be amended. The relief ought

ne+nadzorowane+lub+podlegle/Centra+badawczo+rozwojowe, (accessed: 23 December 2013).

7 In more detail on the construction of the allowance and its use by entrepreneurs, see: (Szlęzak-Matusewicz 2012).

8 This ratio may even amount to -0.02; (Adamczyk 2010, 51). 
to cover current expenditures incurred on research carried out on one's own account.

\section{CONCLUSIONS}

R\&D activity is not only costly but also encumbered by a high risk of failure. In order to stimulate activeness of enterprises in this sphere, in the majority of EU Member States are applied tax incentives in the form of reliefs deducted from income or tax. However, their generosity depends primarily on the construction thereof in individual countries. Notwithstanding, in every case the financial advantage issuing from the relief deployment is apparent. Poland is the only country where the relief has its discouraging effect for entrepreneurs' innovative attitudes. Having this in mind, the relief construction in Poland should be revised. The following changes should be introduced:

- Widening the deduction base volume. Reasonable seems to be introduction of the opportunity to deduct, even within the present construction, current expenditures which are personnel outlays as well as costs of consumption of materials. They amount to almost $70 \%$ of all expenditures incurred by enterprises on R\&D activity. ${ }^{9}$

- Providing access to the tax relief for entrepreneurs taxed by flat rate (19\%) and simplified forms of taxation.

- Introducing clear interpretation what kinds of expenditures can be deducted within the tax relief.

- Increasing the threshold of the deduction from $150 \%$ do $200 \%$ (e.g. Czech Republic, Hungary).

Lack of amendments to the tax regulations in this respect will cause that Poland will be one of not numerous countries where low expenditures on R\&D activities are accompanied by lack of fiscal instruments supporting this sphere what, in turn, may still more enhance the technological gap between Poland and the remaining countries of the European Union.

9 Such an opinion was also provided by A. Adamczyk who had carried out an analysis of the B-index value for Poland; (Adamczyk 2010, 55). 


\section{DEFERENCES}

Adamczyk A. (2010), Propozycje zmian bodźców podatkowych wspierających działalność R\&D polskich przedsiębiorstw, Gospodarka Narodowa, 11-12/2010, 41-60 http://gospodarkanarodowa.sgh.waw.pl/p/gospodarka_narodowa_2010_11-12_03.pdf.

Bal-Woźniak T. (2012), Innowacyjność w ujęciu podmiotowym, Uwarunkowania instytucjonalne, PWE, Warszawa.

Bloom N., Griffith R., Van Reenen J. (2002). Do R\&D tax credits work? Evidence from a panel of countries 1979-1997. Journal of Public Economics, 85(1), 1-31. http:// dx.doi.org/10.1016/S0047-2727(01)00086-X.

Cappelen Å., Raknerud A., Rybalka M. (2012). The effects of R\&D tax credits on patenting and innovations. Research Policy, 41(2), 334-345. http://dx.doi.org/10.1016/j. respol.2011.10.001.

Central Statistical Office (GUS) (2013), Działalność badawcza i rozwojowa w Polsce w 2012 r., http://www.stat.gov.pl/cps/rde/xbcr/szczec/ASSETS_sygnalna_BR_ 2012.pdf (accessed: 21.12.2013).

Central Statistical Office (GUS), http://www.stat.gov.pl/gus/definicje_PLK_HTML. htm?id=POJ-385.htm (accessed: 21.12.2013).

Coad A., Rao R. (2010). Firm growth and R\&D expenditure. Economics of Inno-vation and New Technology, Vol. 19, Issue 2, 127-145. http://dx.doi.org/10.1080/10 438590802472531.

Cordes J.J. (1989). Tax Incentives and R\&D Spending: A Review of the Evidence. Research Policy, 18, 119-133. http://dx.doi.org/10.1016/0048-7333(89)90001-2.

Czarnitzki D., Hanel P., Rosa J. M. (2011). Evaluating the impact of R\&D tax credits on innovation: A microeconometric study on Canadian firms. Research Policy, 40(2), 217-229. http://dx.doi.org/10.1016/j.respol.2010.09.017.

Czerniak J. (2013), Polityka innowacyjna w Polsce, Analiza i proponowane kierunki zmian, Difin, Warszawa.

Deloitte (2013), Przegląd zachęt na działalność B+R na świecie w 2013 r., http://www. deloitte.com/assets/Dcom Poland/Local\%20Assets/Documents/Raporty,\%20badania,\%20rankingi/pl_PrzegladZachetPodatkowych_BiR_2013_marzec.pdf (accessed: 19.12.2013).

Hall B. (1993). R\&D Tax Policy During the Eighties: Success or Failure. Tax Policy and the Economy, 7, 1-36.

Hall B. (1995), Fiscal Policy towards R\&D in the United States: Recent experience, OECD, http://elsa.berkeley.edu/ bhhall/papers/BHH95\%200ECD\%20R\&D.pdf (accessed: 18.12.2013).

Hall B., Van Reenen J. (2000). How effective are fiscal incentives for R\&D? A review of the evidence. Research Policy, 29, 449-469. http://dx.doi.org/10.1016/S00487333(99)00085-2.

http://bip.mg.gov.plChile/Jednostki+organizacyjne+nadzorowane+lub+podlegle/Centra+badawczo+rozwojowe (accessed: 19.12.2013). 
Mansfield E. and Switzer L. (1985). The Effects of R\&D Tax Credits and Allowances in Canada. Research Policy, 14, 97-107. http://dx.doi.org/10.1016/0048-7333(85)90017-4.

Mohnen P. (1999), Tax incentives: Issue and evidence, Cirano, Montreal, http://www.cirano.qc.ca/pdf/publications/99s-32.pdf (accessed: 12.12.2013).

OECD (2011), Tax Reform Options: Incentives for Innovation. The International Experience with R\&D Tax Incentives, http://www.finance.senate.gov/imo/media/ doc/OECD\%20SFC\%20Hearing\%20testimony\%209\%2020\%2011.pdf (accessed: 16.12.2013).

OECD (2012), OECD Science, Technology and Industry Outlook 2012, OECD Publishing.

Romer P. (1990), Endogenous Technological Change, Journal of Political Economy, 98, http://www.jstor.org/discover/10.2307/2937632?uid=3738840\&uid=2\&uid=4\& sid=21103418385683 (accessed: 13.12.2013). http://dx.doi.org/10.1086/261725.

Science, technology and innovation in Europe, 2013 edition (2013), EUROSTAT, http:// epp.eurostat.ec.europa.eu/cache/ITY_OFFPUB/KS-GN-13-001/EN/KS-GN-13-001EN.PDF (accessed: 19.12.2013).

Stewart L. A., Warda J., Atkinson R. D. (2012), We're \#27: The United States lags far behind in R\&D tax incentives generosity, ITIF, http://www2.itif.org/2012-were-27-b-index-tax.pdf (accessed: 07.12.2013).

STI (2004), Tax incentives for research and development: Trends and issues, OECD.

Szlęzak-Matusewicz J. (2012), Zastosowanie preferencji podatkowych w polskich przedsiębiorstwach, 259-269 [in:] Opodatkowanie przedsiębiorstw, J. Iwin-Garzyńska (ed.), Zeszyty naukowe nr 708, Wydawnictwo Naukowe Uniwersytetu Szczecińskiego, Szczecin.

Ustawa z 15 lutego 1992 o podatku dochodowym od osób prawnych (Dz. U. z 2011, poz. 397) [Act of 15 February 1992 on corporate income tax (Journal of Laws of 2011, item 397)].

Ustawa z 26 lipca 1991 o podatku dochodowym od osób fizycznych (Dz.U.z2010, poz. 307) [Act of 26 July 1991 on personal income tax (Journal of Laws of 2010, item 307)].

Walicka M. (2013), Współczesne modele wsparcia podatkowego działalności badawczo-rozwojowej na świecie, 248-259 [in:] Opodatkowanie przedsiębiorstw. Wybrane zagadnienia, J. Iwin-Garzyńska (ed.), Difin, Warszawa.

Warda J. (2006), Treatment of Business Investments in Intellectual Assets: An International Comparison. OECD Science, Technology and Industry Working Papers, 2006/04, OECD, http://www.oecd-ilibrary.org/docserver/download/519pscs408vl. pdf?expires $=1390988263 \&$ id $=i d \&$ accname $=$ guest $\&$ checksum $=22 F 8 D 1 C 93 B 1978 D$ 301F6456CCF05E4B5 (accessed: 12.12.2013).

Wiśniewska J., Janasz K. (ed.) (2013), Innowacje i jakość w zarządzaniu organizacjami, CEDEWU, Warszawa. 